\title{
Leukotriene C4 Binds to Human Glomerular Epithelial Cells and Promotes Their Proliferation In Vitro
}

\author{
Laurent Baud, Josée Sraer, Joëlle Perez, Marie-Paule Nivez, and Raymond Ardaillou \\ INSERM Research Unit 64, Hôpital Tenon, Paris, France
}

\begin{abstract}
In human and experimental glomerulonephritis, glomerular hypercellularity results both from accumulation of macrophages and proliferation of resident glomerular cells. The recent identification of macrophage-derived factors that stimulate mesangial and epithelial cell proliferation suggests that these factors might contribute to the hypercellularity. To determine the identity of such macrophage-derived growth factors, we studied the effect of leukotrienes (LTs), products that are released from macrophages and leukocytes, on proliferation of human glomerular epithelial cells in culture. Dose-dependent (1-100 $\mathrm{nM}$ ) stimulation of $\left[{ }^{3} \mathrm{H}\right]$ thymidine incorporation, an index of cell proliferation, was observed in cells incubated with the sulfidopeptide LTs, LTC4 and LTD4, but not with LTB4. The response was 248 and $172 \%$ of control values at $100 \mathrm{nM}$ LTC4 and LTD4, respectively. This effect of LTC4 was abolished by FPL 55712. Subsequent binding studies demonstrated that glomerular epithelial cells possess specific receptors for LTC4. [ ${ }^{3} \mathrm{H}$ ]LTC4 bound rapidly at $8^{\circ} \mathrm{C}$ to the cells. There was a plateau after $40 \mathrm{~min}$ incubation. Maximum specific binding was 70-90\% of total binding. Specific binding was totally reversible with addition of an excess of unlabeled LTC4. Analysis of time-course association slopes at two concentrations of $\left[{ }^{3} \mathrm{H}\right] \mathrm{LTC} 4$ and of the competition between a single concentration of $\left[{ }^{3} \mathrm{H}\right] \mathrm{LTC} 4$ and increasing concentrations of unlabelled LTC4 ailowed calculation of dissociation constants $\left(K_{d}\right)$ of 220 and $217 \mathrm{nM}$, respectively. Both LTD4 and LTE4 exhibited ED $_{50}$ values that were at least one order of magnitude higher than for LTC4. Thus, our findings suggest that LTC4 binds to specific receptors of glomerular epithelial cells, promotes proliferation of these cells, and could contribute to epithelial hypercellularity found in glomerulonephritis.
\end{abstract}

\section{Introduction}

In human and experimental glomerulonephritis, glomerular hypercellularity results both from infiltration by cells of the monocyte-macrophage series and from proliferation of the resident endothelial, epithelial, and mesangial cells (1-5). Although the precise stimuli for this cellular proliferation are largely unknown, it has been hypothesized that the glomerular

Received for publication 29 November 1984 and in revised form 8 April 1985.

J. Clin. Invest.

(c) The American Society for Clinical Investigation, Inc.

0021-9738/85/07/0374/04 \$1.00

Volume 76, July 1985, 374-377 cell division results from the secretion of growth factors by the infiltrating mononuclear cells $(6,7)$. Indeed, the endothelial cell hyperplasia that occurs in experimental glomerulonephritis depends on the local infiltration by macrophages, as demonstrated in studies using anti-macrophage serum (8). Moreover, the proliferation of mesangial or epithelial cells in culture is enhanced by macrophage-derived factors (9-11). The stimulation of mesangial cell proliferation has been attributed to macrophage interleukin-I (12), but the identity of the macrophage-derived factor(s) that increase the growth of epithelial cells is still unknown (11). The purpose of the present study was to determine whether leukotrienes (LTs), ${ }^{1}$ a class of compounds released characteristically by human mononuclear leukocytes (13), might contribute to epithelial cell proliferation. Our findings indicate that the sulfidopeptide LTs (LTC4 and LTD4), but not LTB4, increase DNA synthesis by human epithelial cells in culture, and that LTC4 binds specifically to these cells.

\section{Methods}

Preparation of epithelial cell cultures. Cortical tissue was prepared from human cadaver kidneys that were judged to be unsuitable for transplantation, and homogeneous populations of glomerular epithelial cells were obtained by collagenase digestion of the isolated glomeruli, as described previously (14). These cells were cultured at $37^{\circ} \mathrm{C}$ in Waymouth's medium (Flow Laboratories, Irvine, United Kingdom) containing $20 \%$ pooled human serum under an humidified atmosphere of $5 \% \mathrm{CO}_{2}$ in air. They were purified further using cloning rings in order to isolate groups of homogeneous cells, and were identified by their morphologic and synthetic characteristics: they are polyhedral, and synthesize predominantly type IV collagen and heparan sulfate (11). For receptor binding assays, the epithelial cells were scraped away from their flasks (14), whereas studies of DNA synthesis were performed on adherent cells.

Measurement of DNA synthesis. Synthesis of DNA by cultured human epithelial cells was determined on day 1 of the third subculture in multidish wells (Nunclon; Nunc, Roskilde, Denmark) before the cells reached confluence. $1 \mu \mathrm{Ci}$ of $\left[{ }^{3} \mathrm{H}\right]$ thymidine $(5 \mathrm{Ci} / \mathrm{mmol}$, Radiochemical Center, Amersham, United Kingdom) was added to each well, which contained $3 \mathrm{ml}$ of RPMI medium (Flow Laboratories) buffered with $20 \mathrm{mM}$ Hepes, $\mathrm{pH} 7.2$, together with the compound to be tested. After $4 \mathrm{~h}$ of incubation at $37^{\circ} \mathrm{C}$ under $5 \% \mathrm{CO}_{2}$ humidified atmosphere, the incorporation of $\left[{ }^{3} \mathrm{H}\right]$ thymidine was stopped by addition of $10 \mu \mathrm{mol}$ of unlabelled thymidine for $30 \mathrm{~min}$. After washing, TCAprecipitable radioactivity was measured by liquid scintillation spectroscopy (1211 Rackbeta; LKB, Bromma, Sverige) as described previously (15). Moreover, in order to verify that enhanced thymidine incorporation

1. Abbreviations used in this paper: DTT, dithiothreitol; LT(s), leukotrienes; LTC4, LTD4, LTE4, and LTB4, leukotrienes C4, D4, E4, and B4; $\mathrm{PGE}_{2}$, prostaglandin E2. 
reflected modification of cell proliferation, the number of cells present in each well was determined $24 \mathrm{~h}$ after addition of the different LTs tested, or the vehicle alone. Statistical analysis of the data was performed using $t$ test for unpaired variables.

Measurement of LTC4 binding. Binding studies were performed in $0.1 \mathrm{ml} 20 \mathrm{mM}$ Tris- $\mathrm{HCl}$ buffer, $\mathrm{pH} 7.4$, containing $125 \mathrm{mM} \mathrm{NaCl}, 10$ $\mathrm{mM} \mathrm{KCl}, 10 \mathrm{mM}$ sodium acetate, $5 \mathrm{mM}$ glucose, $10 \mathrm{mM} \mathrm{CaCl}, 1$ $\mathrm{mM}$ serine-borate, $1 \mathrm{mM}$ dithiothreitol (DTT; Sigma Chemical Co., St. Louis, MO), and $0.1 \mathrm{mM}$ phenylmethylsulfonylfluoride (Sigma Chemical Co.). Solutions of DTT and phenylmethylsulfonylfluoride were prepared immediately before use. Preliminary experiments showed that addition of $1 \mathrm{mM}$ DTT to the incubation medium did not modify $\left[{ }^{3} \mathrm{H}\right] \mathrm{LTC} 4$ binding. The amount of epithelial cell protein varied between 40 and $80 \mu \mathrm{g} /$ tube. The concentration of $\left[{ }^{3} \mathrm{H}\right] \mathrm{LTC} 4(39 \mathrm{Ci} /$ mmol; New England Nuclear, Boston, MA) was 4.9-14.6 nM. Varying amounts of unlabeled ligands (LTC4, LTD4, and LTE4; provided by J. Rokach, Merck-Frost, Kirkland, Canada) or of the LT antagonist, FPL 55712 (Fisons Pharmaceutical, Loughborough, United Kingdom) (16), were added for competition studies. Incubations were performed at $8^{\circ} \mathrm{C}$ for periods between 2 and $50 \mathrm{~min}$. At the end of the incubation period, bound and free $\left[{ }^{3} \mathrm{H}\right] \mathrm{LTC} 4$ were separated by vacuum filtration through Millipore HA filters $(0.45 \mu \mathrm{m})$. The filters were then washed under vacuum three times with $5 \mathrm{ml}$ of ice-cold $20 \mathrm{mM}$ Tris- $\mathrm{HCl}$ buffer, $\mathrm{pH}$ 7.4. The radioactivity remaining on the dried filter was measured in $8 \mathrm{ml}$ scintillation solvent (ACS II, Radiochemical Center). Nonspecific binding was defined as that measured in the presence of an excess $(3 \mu \mathrm{M})$ of unlabeled LTC4. Specific binding was calculated as the difference between total and nonspecific binding. To determine the extent of $\left[{ }^{3} \mathrm{H}\right] \mathrm{LTC} 4$ metabolism during binding experiments, epithelial cells and their medium obtained after 40 min incubation were filtered under vacuum through Whatman GF/C glass fiber filters. The filters were washed three times with ice-cold Tris- $\mathrm{HCl}$ buffer, and the radioactivity remaining on the filter was extracted immediately with $1 \mathrm{ml}$ methanol at $-20^{\circ} \mathrm{C}$. Metabolites of $\left[{ }^{3} \mathrm{H}\right] \mathrm{LTC} 4$ were purified using reverse-phase high performance liquid chromatography (17) and identified by comparison of their retention times with those of authentic standards.

\section{Results}

Incorporation of $\left[{ }^{3} \mathrm{H}\right]$ thymidine. The rate of synthesis of DNA by human glomerular epithelial cells varied in response to the different LTs tested (Fig. 1). Addition of LTC4 resulted in a dose-dependent stimulation of $\left[{ }^{3} \mathrm{H}\right]$ thymidine incorporation at concentrations between 1 and $100 \mathrm{nM}$. LTD4 also promoted an increase of $\left[{ }^{3} \mathrm{H}\right]$ thymidine incorporation at similar concentrations, but the degree of stimulation was less than with LTC4 ( 172 vs. $248 \%$ of control). LTB4 was inactive even at $100 \mathrm{nM}$. Preincubation with medium containing FPL 55712, $2 \mu \mathrm{g} / \mathrm{ml}$ $(3.8 \mu \mathrm{M})$, clearly reduced the effect of LTC4. Moreover, addition of LTC4 and LTD4 $(0.1 \mu \mathrm{M})$ for $24 \mathrm{~h}$ resulted also in an increase of the cell number present in each well (163 and $129 \%$ of control, respectively) (Table I), which confirmed that enhanced thymidine incorporation reflected increased cell proliferation.

Characteristics of $\left[{ }^{3} \mathrm{H}\right]$ LTC 4 binding. $\left[{ }^{3} \mathrm{H}\right] \mathrm{LTC} 4$ binding reached a plateau within $40 \mathrm{~min}$ and remained stable up to $50 \mathrm{~min}$ (Fig. 2). At equilibrium, nonspecific binding represented $10-30 \%$ of total binding. Under these conditions, addition of $3 \mu \mathrm{M}$ unlabeled LTC4 produced a rapid dissociation of the ligand-receptor complex. The half-time of dissociation graphically derived from Fig. 2 was $1 \mathrm{~min}$, and the total radioactivity bound reached the level of nonspecific binding within $4 \mathrm{~min}$. When the time-course of $\left[{ }^{3} \mathrm{H}\right] \mathrm{LTC} 4$ binding to epithelial cells was studied at two different concentrations (4.9 and $14.6 \mathrm{nM}$ ),

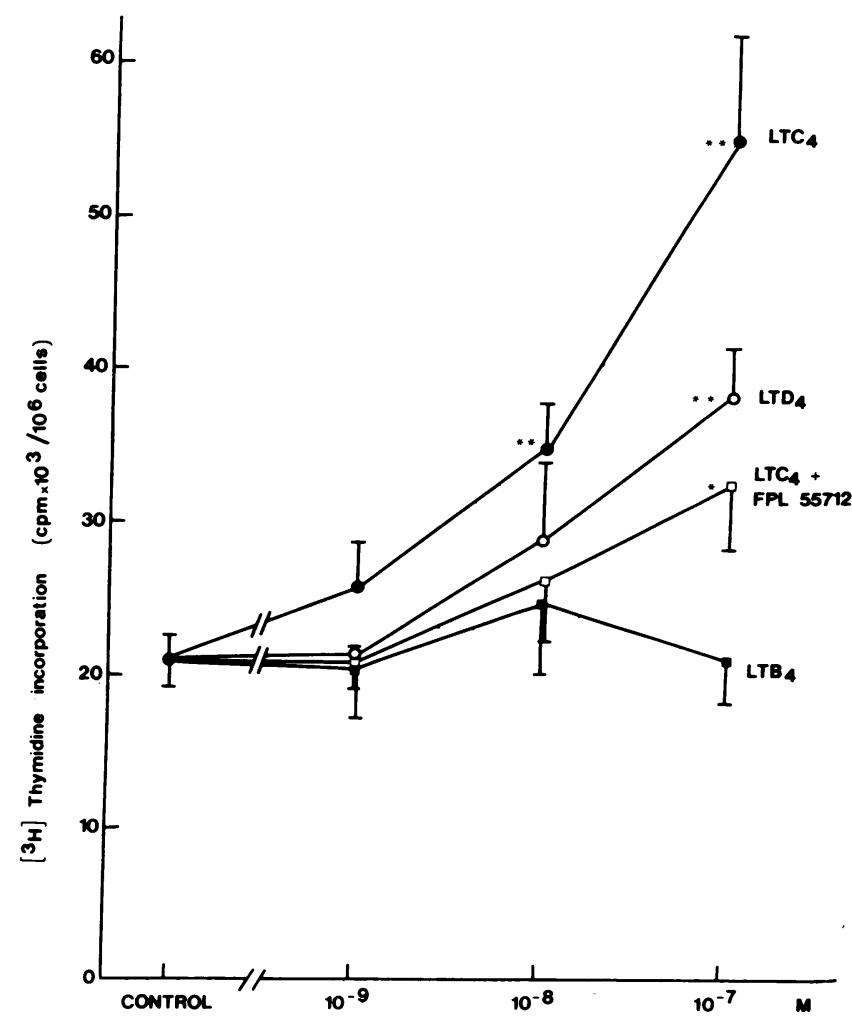

Figure 1. Effect of various LTs on $\left[{ }^{3} \mathrm{H}\right]$ thymidine incorporation by human glomerular epithelial cells. The results are expressed as cpm of $\left[{ }^{3} \mathrm{H}\right]$ thymidine $\times 10^{3}$ incorporated by $10^{6}$ cells after $4 \mathrm{~h}$ of incubation. The data are plotted as the mean \pm SEM of the averages of duplicate results obtained in three or four different experiments. *, $P<0.01 ; * *, P<0.001$.

analysis of the slopes of the two logarithmically transformed association curves yielded a $K_{d}$ of $220 \mathrm{nM}$. To determine the stereospecificity of the $\left[{ }^{3} \mathrm{H}\right] \mathrm{LTC} 4$ binding sites, two additional sulfidopeptide LTs and FPL 55712 were tested for their capacity to inhibit the specific binding of $\left[{ }^{3} \mathrm{H}\right]$ LTC4 (Fig. 3 ). Leukotrienes C4, D4, and E4 inhibited [ $\left.{ }^{3} \mathrm{H}\right] \mathrm{LTC} 4$ binding in a concentration-dependent manner. The Scatchard transformation of the data obtained at $5 \mathrm{nM}$ to $5 \mu \mathrm{M}$ LTC4 allowed calculation of the receptor density $(4.5 \mathrm{pmol} / \mathrm{mg})$ and of the $K_{d}$ value $(217 \mathrm{nM})$. The latter parameter was nearly identical to that derived from kinetic studies. LTD4 and LTE4 were more than one order of magnitude less active, and FPL 55712 was minimally active. The bound radioactivity recovered at

Table I. Effect of Various LTs on Epithelial Cell Proliferation

\begin{tabular}{lcl}
\hline Addition & Cell numbers $\times 10^{3}$ & $\begin{array}{l}\text { Statistical } \\
\text { significance }\end{array}$ \\
\hline None $(n=9)^{*}$ & $73.22 \pm 4.22$ & \\
LTB4 $(n=6)$ & $67.08 \pm 6.53$ & NS \\
LTC4 $(n=7)$ & $119.12 \pm 8.48$ & $P<0.001^{*}$ \\
LTD4 $(n=8)$ & $94.09 \pm 2.95$ & $P<0.005$
\end{tabular}

Values are cell numbers per well after $24 \mathrm{~h}$ incubation. Each value represents the mean \pm SEM. $n$, number of experiments. * Unpaired $t$ test for stimulated versus control. 


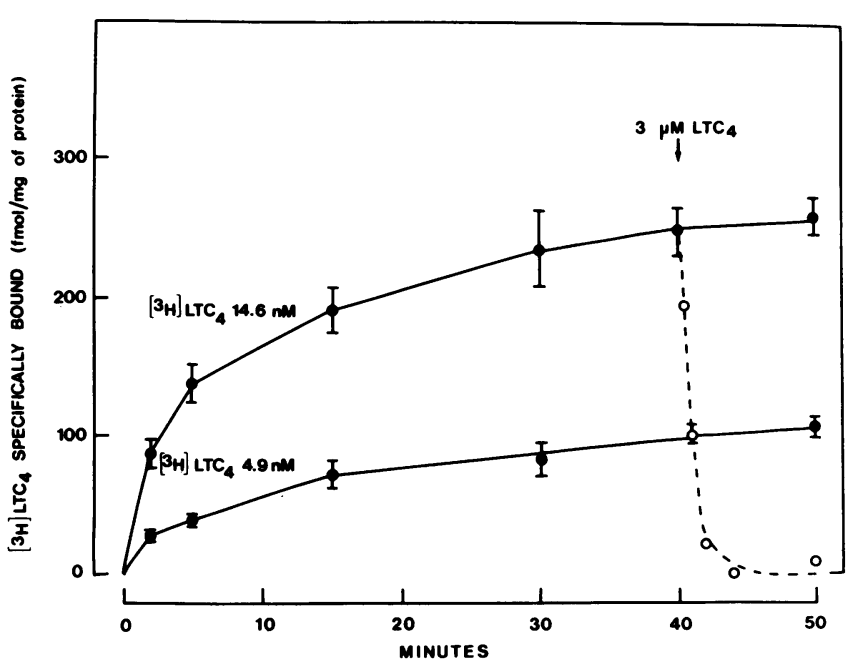

Figure 2. Time-course of specific binding (filled circles) of $\left[{ }^{3} \mathrm{H}\right] \mathrm{LTC} 4$ to human glomerular epithelial cells at two different concentrations of $\left[{ }^{3} \mathrm{H}\right]$ LTC4 (4.9 and $\left.14.6 \mathrm{nM}\right)$. The data are plotted as the mean \pm SEM of the average of duplicate results obtained in four different experiments. After equilibrium was reached at $40 \mathrm{~min}, 3$ $\mu \mathrm{M}$ unlabeled LTC4 was added to those incubation mixtures indicated by the unfilled circles (means of two determinations).

the end of a 40 -min binding assay at $8^{\circ} \mathrm{C}$ was $72 \%\left[{ }^{3} \mathrm{H}\right] \mathrm{LTC} 4$, as demonstrated by high performance liquid chromatography analysis. The remaining radioactivity eluted with unlabeled LTD4 standard $(7.6 \%)$ or as polar impurities $(7.9 \%)$.

\section{Discussion}

Our results demonstrate that the sulfidopeptide LTs, LTC4 and LTD4, stimulate the proliferation of cultured human epithelial cells estimated both by thymidine incorporation and counting of the cells. This stimulatory effect of LTs was previously unknown, whereas prior investigations provided evidence for an inhibitory effect of other arachidonic acid metabolites on cell proliferation. For example, prostaglandin $E_{2}\left(P E_{2}\right)$ has been shown to inhibit thymidine incorporation by human fibroblasts (18) and mouse mesangial cells in culture (19). The concentrations of $\mathrm{PGE}_{2}$ required to obtain a significant

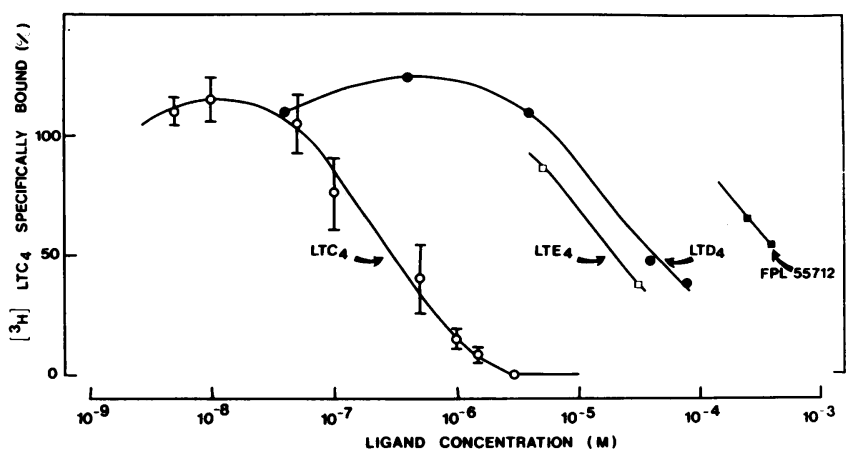

Figure 3. Percentage of inhibition of specific $\left[{ }^{3} \mathrm{H}\right] \mathrm{LTC} 4$ binding by increasing concentrations of LTC4, LTD4, LTE4, and FPL 55712. The data are plotted as the mean of the results obtained in two experiments, except for LTC4 (three experiments). inhibition of glomerular cell growth ranged between 10 and $100 \mathrm{nM}$ (19), concentrations identical with those of LTC4 and LTD4 required for stimulation of epithelial cell growth in the present study. Moreover this biological effect of LTC4 occurs at doses known to promote other physiological effects, such as prostacyclin synthesis by human endothelial cells in vitro (20), and increased vascular permeability in vivo (21).

The effect of LTC4 on epithelial cell proliferation was counteracted by the LT antagonist FPL 55712. Such a characteristic of LTC4 activity has been described previously in the whole kidney in studies in which the vasoconstriction induced by LTC4 infusion in vivo was also abolished by FPL 55712 (22). Our results also demonstrate that $\left.{ }^{3} \mathrm{H}\right] \mathrm{LTC} 4$ binds to human epithelial cells. The binding properties observed including saturability, rapid association, reversibility, and stereospecificity, together with the low rate of degradation of the bound ligand, are consistent with an LTC4 receptor. Specific $\left[{ }^{3} \mathrm{H}\right] \mathrm{LTC} 4$ binding to human epithelial cells at $8^{\circ} \mathrm{C}$ reached a plateau at $40 \mathrm{~min}$, represented $>70 \%$ of the total binding, and was totally reversible by unlabeled LTC4. A similar timecourse has been reported for the binding of $\left[{ }^{3} \mathrm{H}\right] \mathrm{LTC} 4$ to smooth muscle cell lines (23), and to isolated rat renal glomeruli (24). The $K_{d}$ values calculated from both association slopes at two concentrations of $\left[{ }^{3} \mathrm{H}\right] \mathrm{LTC} 4(220 \mathrm{nM})$ and from analysis of the competition between a single concentration of $\left[{ }^{3} \mathrm{H}\right] \mathrm{LTC} 4$ and incremental concentrations of unlabeled LTC4 (217 nM) were greater than those described for smooth muscle cell lines (5 nM) (23) or for isolated rat renal glomeruli (50 nM) (24). This discrepancy in the $K_{d}$ values could be explained by the modification of receptor characteristics during culture of glomerular cells, by differences between homogeneous and heterogeneous populations of cells, or by assuming that isolated glomeruli from murine and human origin possess different specific LTC4 receptors.

The physiological mechanism by which LTC4 binding promotes epithelial cell proliferation is unknown. Inasmuch as stimulation of epithelial cell proliferation by sulfidopeptide LTs and binding of LTC4 to specific cellular receptors were observed over a similar range of concentrations, it seems possible that the two events are linked. However, the fact that FPL 55712 inhibited LTC4-induced increase in cell proliferation cannot be taken as evidence for a receptor-mediated event, since this drug was a very poor competitor for $\left[{ }^{3} \mathrm{H}\right] \mathrm{LTC} 4$ binding. Similarly, the stimulatory effect of LTD4 on cell proliferation was greater than what could have been expected from the competitive inhibition binding studies. Possibly, FPL 55712 acted at a postreceptor stage and LTD4 bound to LTR 1 receptors which have been shown to be distinct from the highaffinity receptors for LTC4 (LTR2) (25). Further studies are necessary to demonstrate that the proliferative response to LTC4 is indeed receptor mediated. Because it has been shown that LTs decrease tissue cyclic AMP content (26), and that cyclic AMP has an inhibitory role on cell growth (18), it could be inferred that the effects of LTs on epithelial cell proliferation are related to an inhibition of adenylate cyclase. Additional biochemical investigations will be required to clarify this mechanism.

\section{Acknowledgments}

We are very grateful to Dr. Rokach for supplying the unlabeled leukotrienes and to Dr. P. Sheard for supplying FPL 55712. We are 
also indebted to Prof. Morris Schambelan for helpful discussion of the data. Mrs. Knobloch and Brocherieu gave excellent secretarial assistance.

This work was supported by grants from the Institut National de la Santé et de la Recherche Médicale and from the Faculté de Médecine Saint Antoine.

\section{References}

1. Holdsworth, S. R., N. M. Thomson, E. F. Glasgow, J. P. Dowling, and R. C. Atkins. 1978. Tissue culture of isolated glomeruli in experimental crescentic glomerulonephritis. J. Exp. Med. 147:98109.

2. Schreiner, G. F., R. S. Cotran, V. Pardo, and E. R. Unanue. 1978. A mononuclear cell component in experimental immunological glomerulonephritis. J. Exp. Med. 147:369-384.

3. Atkins, R. C., E. F. Glasgow, S. R. Holdsworth, N. M. Thomson, and W. W. Hancock. 1980. Tissue culture of isolated glomeruli from patients with glomerulonephritis. Kidney Int. 17:515-527.

4. Cattell, V., and S. W. Jamieson. 1978. The origin of glomerular crescents in experimental nephrotoxic serum nephritis in the rabbit. Lab. Invest. 39:584-590.

5. Sterzel, R. B., and R. Pabst. 1982. The temporal relationship between glomerular cell proliferation and monocyte infiltration in experimental glomerulonephritis. Virchows Arch. B Cell Pathol. 38: 337-350.

6. Cotran, R. S. 1978. Monocytes, proliferation, and glomerulonephritis. J. Lab. Clin. Med. 92:837-840.

7. Atkins, R. C., S. R. Holdsworth, W. W. Hancock, N. M. Thomson, and E. F. Glasgow. 1982. Cellular immune mechanisms in human glomerulonephritis: the role of mononuclear leucocytes. Springer Semin. Immunopathol. 5:269-296.

8. Holdsworth, S. R., T. J. Neale, and C. B. Wilson. 1981. Abrogation of macrophage-dependent injury in experimental glomerulonephritis in the rabbit. Use of an antimacrophage serum. J. Clin. Invest. 68:686-698.

9. Striker, G. E., P. D. Killen, and F. M. Farin. 1980. Mesangial cell proliferation, role of macrophages and platelets. Fed. Proc. 39:334. (Abstr.)

10. Dubois, C. H., J. B. Foidart, M. B. Hautier, C. A. Dechenne, M. J. Lemaire, and P. R. Mahieu. 1981. Proliferative glomerulonephritis in rats: evidence that mononuclear phagocytes infiltrating the glomeruli stimulate the proliferation of endothelial and mesangial cells. Eur. $J$. Clin. Invest. 11:91-104.

11. Striker, G. E., P. D. Killen, and F. M. Farin. 1980. Human glomerular cells in vitro: isolation and characterization. Transplant. Proc. 12:88-99.

12. Lovett, D., B. Sterzel, and J. Rayan. 1984. Stimulation of rat mesangial cell proliferation by macrophage Interleukin I. Kidney Int. 25:214. (Abstr.)

13. Williams, J. D., J. K. Czop, and K. F. Austen. 1984. Release of leukotrienes by human monocytes on stimulation of their phagocytic receptor for particulate activators. J. Immunol. 132:3034-3040.

14. Ardaillou, N., M.-P. Nivez, G. Striker, and R. Ardaillou. 1983. Prostaglandin synthesis by human glomerular cells in culture. Prostaglandins. 26:773-784.

15. Keast, D., and W. N. Bartholomaeus. 1973. Liquid scintillation technique for the determination of DNA synthesis of lymphocytes cultured in plastic vessels. J. Immunol. Methods. 2:261-267.

16. Augstein, J., J. B. Farmer, T. B. Lee, P. Sheard, and M. L. Tattersall. 1973. Selective inhibitor of slow reacting substance of anaphylaxis. Nature (Lond.). 245:215-217.

17. Mathews, W. R., J. Rokach, and R. C. Murphy. 1981. Analysis of leukotrienes by high-pressure liquid chromatography. Anal. Biochem. 118:96-101.

18. Korn, J. H., P. V. Halushka, and E. C. Le Roy. 1980. Mononuclear cell modulation of connective tissue function. Suppression of fibroblast growth by stimulation of endogenous prostaglandin production. J. Clin. Invest. 65:543-554.

19. Ooi, Y. M., M. A. Weiss, A. Hsu, and B. S. Ooi. 1983. Mechanisms of suppression of mouse mesangial cell proliferation by macrophage supernatants. J. Immunol. 130:1790-1795.

20. Cramer, E. B., L. Pologe, N. A. Pawlowski, Z. A. Cohn, and W. A. Scott. 1983. Leukotriene C promotes prostacyclin synthesis by human endothelial cells. Proc. Natl. Acad. Sci. USA. 80:4109-4113.

21. Dahlen, S. E., J. Björk, P. Hedquist, K. E. Arfors, S. Hammarström, J. A. Lindgren, and B. Samuelsson. 1981. Leukotrienes promote plasma leakage and leukocyte adhesion in postcapillary venules: in vivo effects with relevance to the acute inflammatory response. Proc. Natl. Acad. Sci. USA. 78:3887-3891.

22. Badr, K. F., C. Baylis, J. M. Pfeffer, M. A. Pfeffer, R. J. Soberman, R. A. Lewis, K. F. Austen, E. J. Corey, and B. M. Brenner. 1984. Renal and systemic hemodynamic responses to intravenous infusion of leukotriene C4 in the rat. Circ. Res. 54:492-499.

23. Krilis, S., R. A. Lewis, E. J. Corey, and K. F. Austen. 1983. Specific receptors for leukotriene $\mathrm{C} 4$ on a smooth muscle cell line. $J$. Clin. Invest. 72:1516-1519.

24. Ballermann, B. J., R. A. Lewis, E. J. Corey, K. F. Austen, and B. M. Brenner. 1984. Characterization of specific leukotriene C4 (LTC4) receptors in isolated rat renal glomeruli. IXth Int. Cong. Nephrology. 443A. (Abstr.)

25. Lewis, R. A., and K. F. Austen. 1984. The biologically active leukotrienes. Biosynthesis, metabolism, receptors, functions, and pharmacology. J. Clin. Invest. 73:889-897.

26. Hedman, S. E., and R. G. G. Andersson. 1982. Effects of SRS (slow reacting substance) on cyclic nucleotides in guinea-pig tracheal muscle. Acta Pharmacol. Toxicol. 50:30-34. 